Check for updates

Cite this: RSC Adv., 2017, 7, 38853

Received 16th May 2017

Accepted 28th July 2017

DOI: 10.1039/c7ra05520j

rsc.li/rsc-advances

\section{Graphene oxide loaded with copper oxide nanoparticles as an antibacterial agent against Pseudomonas syringae pv. tomato}

\begin{abstract}
Yadong Li, (D) a Desong Yang ${ }^{* a}$ and Jianghu Cui (D) *b
Bacterial speck caused by Pseudomonas syringae pv. tomato (Pst) is a major disease of tomatoes. Infection by Pst in the seedling stage could cause $75 \%$ of total yield loss and quality losses in tomatoes. Applying massive chemical bactericides to control this disease has caused undesirable pathogen resistance, environmental pollution, and threats to humans. Here, we developed a candidate antibacterial agent made from copper oxide nanoparticles loaded onto the surfaces of graphene oxide sheets (GO-Cu NPs). A series of characterization measurements showed that the nanocomposite had been successfully prepared. Antibacterial activity results indicated that GO-Cu NPs had a 16-times higher antibacterial activity than Kocide 3000. From further investigation, the GO-Cu NPs composite could lead to damaging the cell structure, increasing the level of reactive oxygen species, and decreasing the content of DNA in Pst cells. From an in vivo test, GO-Cu NPs at 4 and $8 \mu \mathrm{g} \mathrm{m}^{-1}$ significantly reduced the severity of bacterial speck below $25 \%$ and the tomatoes had no phytotoxicity. Comparatively, 125 and $250 \mu \mathrm{g} \mathrm{mL} \mathrm{m}^{-1}$ were required for Kocide 3000 to achieve similar effects. Therefore, GO-Cu NPs composites as a high-efficiency biocide have great potential for managing crop diseases.
\end{abstract}

\section{Introduction}

Tomato (Lycopersicon esculentum) is the second most important vegetable crop. Food and Agriculture Organization (FAO) statistics show the current world production of tomatoes was about 170 million tons in 2014. Bacterial speck is a serious bacterial disease in the tomato industry caused by Pseudomonas syringae pv. tomato (Pst). Pst can result in small, sunken, and black lesions on leaves, stems, and fruits. ${ }^{1}$ According to previous literature, infection of Pst in the seedling stage could cause $75 \%$ total yield loss and significant reduction of tomato quality. ${ }^{2}$ Due to this significant harmfulness, bacterial speck has been the target of numerous studies on control measures for protecting tomato, including biological control and chemical control. It has been reported that some bacteria, such as Bacillus pumilus and Bacillus amyloliquefacies, could efficiently control tomato bacterial speck. ${ }^{3}$ However, environmental conditions are always adverse for a biocontrol organism to exert antibacterial activity. On the other hand, implementation of biocontrol requires more labour and economic costs. Therefore, it is difficult for biocontrol to be widely applied in the agricultural industry. Chemical agents provide convenient and quick

${ }^{a}$ College of Agriculture, Shihezi University, Shihezi 832000, Xinjiang, P. R. China. E-mail: yds_agr@shzu.edu.cn

${ }^{b}$ Guangdong Key Laboratory of Integrated Agro-Environmental Pollution Control and Management, Guangdong Institute of Eco-Environmental Science \& Technology, Guangzhou 510650, China.E-mail: lantian9426@163.com methods to control bacterial speck in tomatoes. Both streptomycin and copper biocide are regarded as the most effective and commonly used agents for control of bacterial speck with tomatoes. $^{4,5}$ However, long term use of these biocides has induced undesirable pathogen resistance. ${ }^{6,7}$ Besides, residues of these agents in soil and food are harmful to the environment and human health. ${ }^{8}$ Therefore, it is urgent to develop alternative bactericides to protect tomatoes from Pst infection.

Recently, inorganic nano-biocides, such as silver, ${ }^{\mathbf{9}, 10}$ titanium dioxide, ${ }^{11}$ and zinc oxide, ${ }^{12}$ have been of great interest in applications for plant disease management. Especially silverbased antibacterial agents have been widely studied due to their good antibacterial activity. ${ }^{\mathbf{1 3 , 1 4}}$ In our previous studies, we prepared some silver-based composites with graphene oxide (GO) ${ }^{15}$ silicon oxide nanospheres, ${ }^{16}$ and porous carbon. ${ }^{17}$ These nanocomposites showed excellent antibacterial activity against Escherichia coli and Xanthomonas oryzae pv. oryzae. However, the practical application of silver composites has been limited due to their high cost and phytotoxicity. Thus, many researchers are searching for an inorganic alternative with low cost and toxicity. Copper biocides also have been used widely in crop disease control as a result of their wide antimicrobial spectrum and low cost. For example, Young et al. and Bogdanovic et al. found that $\mathrm{Cu}$ nanoparticles (Cu NPs) had greatly enhanced antibacterial activity against bacteria. ${ }^{\mathbf{1 8 , 1 9}} \mathrm{In}$ addition, it was reported that $\mathrm{Cu}$ NPs were beneficial to growth and nutriment accumulation of Vigna radiate and maize..$^{\mathbf{2 0 2 1}}$ However, pure $\mathrm{Cu}$ NPs are easy to agglomerate, leading to decrease of antibacterial activity. ${ }^{22}$ In 
order to address this problem, we are searching for a suitablybased material to reduce the agglomeration of Cu NPs.

With excellent physical and chemical properties, GO has been widely used in biomedicine, the environment, and agriculture. ${ }^{23-26}$ As a result of hydrophilic reactive oxygen functional groups on its surface, GO tends to readily disperse in water. ${ }^{27}$ Chen et al. reported that GO had a broad-spectrum bactericidal efficacy toward plant pathogenic bacteria and fungi. ${ }^{23}$ And Ocsoy et al. prepared DNA-directed Ag NPs grown on GO which efficiently could control bacterial spots with tomatoes. ${ }^{13}$ Our previous study showed also that GO and silver nanowire composites could have improved antibacterial activity with better cell compatibility. ${ }^{15}$ In addition, Zhang et al. reported that graphene had a positive impact on promoting seed germination and seedling growth of tomatoes. ${ }^{28}$ Thus, GO was believed to be an ideal host material to load with Cu NPs. Here, we report a Cu-based nano-biocide where $\mathrm{Cu}$ nanoparticles (Cu NPs) were immobilized on the surfaces of GO sheets (GO-Cu NPs) with good antibacterial activity toward Pst. A series of characterization tests were conducted for particle size, morphology, element composition, and surface structure of the prepared GO-Cu NPs. We further propose that $\mathrm{GO}-\mathrm{Cu}$ NPs have the ability to induce cell membrane damage, oxidative stress mediated by reactive oxygen species (ROS), and degradation of DNA. Finally, with tomato transplants, GO-Cu NPs at an extremely low concentration reduced the severity of bacterial speck without phytotoxicity, similarly with the current standard treatment.

\section{Experimental section}

\subsection{Materials}

Cupric chloride was obtained from Guangzhou Chemical Reagent Factory (Guangzhou, China). Graphite and $\mathrm{KMnO}_{4}$ were purchased from Shanghai Chemical Factory (Shanghai, China). $25 \%$ glutaraldehyde was obtained from Chengdu Kelong Chemical Factory (Chengdu, China). 2,7Dichlorofluorescein-diacetate (DCFH-DA) was purchased from BD Biosciences (CA, USA). Kocide 3000 (46.1 wt\%, cupric hydroxide) is a bactericide product of DuPont (Wilmington, DE, USA). Other chemical reagents in this study were analytical grade and used without further purification. Water was purified by using an ultrapure water system (Pine-Tree, China). Pseudomonas syringae pv. tomato (Pst) strain was obtained from an agricultural college, Shihezi University (Shihezi, China). This strain was originally derived from an infected tomato leaf with bacterial speck in an experimental field at Shihezi University.

\subsection{Preparation of graphene oxide sheets}

GO powder was prepared through oxidation of natural flake graphite powder according to a modified Hummers' method. ${ }^{29}$ Briefly, graphite powder $(1 \mathrm{~g})$ was loaded into concentrated $\mathrm{H}_{2} \mathrm{SO}_{4}(98 \%, 23 \mathrm{~mL})$ with vigorous stirring for $30 \mathrm{~min}$ in an ice bath. Subsequently, $\mathrm{KMnO}_{4}(3 \mathrm{~g})$ was added gradually to the mixture with continuous stirring for $2 \mathrm{~h}$ below $10^{\circ} \mathrm{C}$. Then the mixture was warmed to $35{ }^{\circ} \mathrm{C}$ and stirred continuously for another $2 \mathrm{~h}$, followed by slow addition of $46 \mathrm{~mL}$ distilled water and stirring for another $20 \mathrm{~min}$. Finally, $140 \mathrm{~mL}$ distilled water was added to terminate the reaction. Then, $30 \% \mathrm{H}_{2} \mathrm{O}_{2}$ was added and the colour of the mixture changed to bright yellow. The sample was washed with repeated centrifugation with an $\mathrm{HCl}$ solution and distilled water. The sediment was dried in vacuum and GO powder was obtained.

\subsection{Preparation and characterization of GO-Cu NPs composites}

Cupric chloride was reduced and immobilized on the surfaces of GO sheets by ammonia water. Briefly, $40 \mathrm{mg}$ GO powder was dissolved in $40 \mathrm{~mL}$ distilled water and flaked into a homogeneous GO suspension by sonication for $30 \mathrm{~min}$. Then, $2 \mathrm{~g}$ cupric chloride was added into the GO suspension and kept stirring for $30 \mathrm{~min}$. Then, $1 \mathrm{~mL}$ ammonia water was quickly added into the mixture with vigorous stirring for $1 \mathrm{~h}$. After that, the obtained samples were washed three times with deionized water with centrifugation. The sample was dried in vacuum for further measurements.

Morphology of the composites was investigated with a Philips TECNAI 10 transmission electron microscope (TEM). Samples for TEM tests were prepared by placing a drop of solution dispersion onto carbon-coated copper grids and drying at room temperature. Elemental composition was analyzed with a JEOL JEM2100F high-resolution TEM (HRTEM) equipped with an Oxford INCA energy-dispersive X-ray spectroscopy (EDS) device. Microstructures of the obtained samples were recorded on a MSAL-XD2 $\mathrm{X}$-ray diffractometer (XRD) employing $\mathrm{Cu}$ target in the $2 \theta$ range from $5^{\circ}$ to $80^{\circ}(40 \mathrm{kV}, 30 \mathrm{~mA}, \lambda=1.54051 \AA)$. Interactions of GO with $\mathrm{Cu}$ NPs were carried out with a Nicolet Avatar-300 Fourier transform infrared (FTIR) spectrophotometer.

\subsection{Antibacterial assays}

To explore the antibacterial properties of GO-Cu NPs, Pst was introduced for measurements of agar disk diffusion and minimum inhibitory concentration (MIC) tests. GO and sterile water served as negative controls. The presence of antibacterial activity of GO-Cu NPs was affirmed through agar disk diffusion tests. ${ }^{30}$ Briefly, Pst cells were incubated in King's B broth with shaking at $25{ }^{\circ} \mathrm{C}$ and $180 \mathrm{rpm}$ overnight. Then the bacteria suspension was diluted to an optical density at $600 \mathrm{~nm}\left(\mathrm{OD}_{600}\right)$ of $0.1\left(\sim 1 \times 10^{8} \mathrm{cfu} \mathrm{mL}^{-1}\right)$. A $100 \mu \mathrm{L}$ bacterial suspension was swabbed over a King's B agar plate. Filter paper discs, beforehand immersed in sterile water, GO, GO-Cu NPs, and Kocide 3000 , respectively, were placed on a plate. After incubating at $25{ }^{\circ} \mathrm{C}$ for $48 \mathrm{~h}$, the size of the inhibition zone around the filter papers was measured. To further evaluate the antibacterial activity level of GO-Cu NPs, MIC was measured according to the broth dilution method. ${ }^{31}$ Kocide 3000 was tested synchronously as a reference. First, the Pst suspension was incubated with different concentrations of GO-Cu NPs or Kocide 3000 (0 to $250 \mu \mathrm{g} \mathrm{mL}{ }^{-1}$ ) at $25{ }^{\circ} \mathrm{C}$ and $180 \mathrm{rpm}$ for $2 \mathrm{~h}$. Then, $100 \mu \mathrm{L}$ from each treatment was evenly coated on King's B agar plates. The MIC was recorded as the lowest concentration at which no visible colonies grew after being inoculated at $25{ }^{\circ} \mathrm{C}$ for $48 \mathrm{~h} .{ }^{16}$ All experiments were repeated three times. 


\subsection{Cell morphology observation}

To observe morphological changes of bacterial cells after treatment with the GO-Cu NPs composites, Pst cells were exposed to the GO-Cu NPs composites $\left(32 \mu \mathrm{g} \mathrm{mL}{ }^{-1}\right)$. Sterile water served as a control treatment. All the samples were harvested by centrifugation at $12000 \mathrm{rpm}$ for $3 \mathrm{~min}$ and washed three times with phosphate buffered saline. After that, the condensed bacteria were fixed with $2.5 \%$ glutaraldehyde overnight at $4{ }^{\circ} \mathrm{C}$ and postfixed with $1 \%$ aqueous osmic acid for $2 \mathrm{~h}$. Then the samples were rinsed with buffer and dehydrated in an ascending ethanol series $(50 \%, 70 \%, 80 \%, 90 \%$, and $100 \%)$ for $15 \mathrm{~min}$, respectively. Subsequently, the samples were embedded in Epon/Araldite resin according to a standard protocol. Finally, thin sections containing the cells were stained with $4 \%$ uranyl acetate and $0.2 \%$ Reynolds lead citrate and then air-dried for TEM detection.

\subsection{Measurement of intracellular reactive oxygen species} (ROS)

To determine generation of ROS in Pst cells, an indicator of ROS, 2,7-dichlorofluorescein diacetate (DCFH-DA), was introduced into this experiment. DCFH-DA can easily enter a cell and be hydrolysed by cellular esterase into DCFH. Subsequently, DCFH reacts with intracellular ROS to produce highly fluorescent dichlorofluorescein (DCF). Fluorescence intensity is proportional to the amount of ROS. ${ }^{32}$ Herein, Pst suspensions were treated with GO-Cu NPs, GO, and sterile water respectively for $2 \mathrm{~h}$ at $25^{\circ} \mathrm{C}$ and $180 \mathrm{rpm}$. Then the Pst cells were strained with DCFHDA for $30 \mathrm{~min}$ and washed twice with phosphate buffered saline in darkness. Fluorescent intensity of DCF was measured by flow cytometry with an excitation wavelength of $488 \mathrm{~nm}$. For each sample, 20000 cells were measured for the mean fluorescent intensity to present the intracellular generation of ROS.

\subsection{Analysis of DNA content}

To investigate the degradation of DNA in Pst cells treated with GO-Cu NPs, DNA kits (Tiangen, Beijing, China) were employed to extract the DNA from Pst cells. Before the operation, Pst was allowed to inoculate in King's B broth and incubated under $25^{\circ} \mathrm{C}$ and $180 \mathrm{rpm}$ overnight. The experiments were carried out in Pst suspensions $\left(\mathrm{OD}_{600}=0.3\right)$ containing $0,8,16,32,62.5$, and $125 \mu \mathrm{g} \mathrm{mL} \mathrm{m}^{-1}$ of GO-Cu NPs. After being inoculated at $25^{\circ} \mathrm{C}$ and $180 \mathrm{rpm}$ for $2 \mathrm{~h}, 2 \mathrm{~mL}$ of cell suspension from each treatment was pelleted in a microcentrifuge. The DNA was isolated and dissolved in $50 \mu \mathrm{L}$ buffer according to specifications of the kits. Subsequently, $10 \mu \mathrm{L}$ of each DNA solution was mixed thoroughly with $2 \mu \mathrm{L} 6 \times$ DNA loading buffer (Beijing TransGen Biotech Co., Ltd., China) and electrophoresis was conducted in $1 \%$ agarose gel using ethidium bromide to stain. DNA concentration was determined by the intensity of the DNA band observed from the gel imaging and analysis system (Bio-Rad, USA).

\subsection{Greenhouse experiment}

To evaluate the control effect of GO-Cu NPs against the bacterial speck in tomatoes, an in vivo study was conducted on tomato transplants of the cultivar "Shi Hong 9". Tomato plants were grown in plastic pots containing cultivated soil in a greenhouse. After growing to a five-leaf stage, GO-Cu NPs at 4 and $8 \mu \mathrm{g} \mathrm{mL}{ }^{-1}$ were sprayed onto the tomato leaves. Plants treated with Kocide 3000 (125 and $250 \mu \mathrm{g} \mathrm{mL}{ }^{-1}$ ) and sterile water were kept as controls. Each treatment was repeated five times. Two hours after treatment, Pst was inoculated on these treated plants by spraying. All the treated leaves of the tomatoes were bagged with transparent plastic bags after the infection of Pst. After $48 \mathrm{~h}$, the bags were opened and all plants were placed in a greenhouse at $20-25{ }^{\circ} \mathrm{C}$ and $\geq 70 \%$ relative humidity. Then the percentage of bacterial speck severity was recorded at the 4th, 7th, and 10th days according to a method reported by Ocsoy. ${ }^{13}$ The disease severity was calculated according to the following formula:

$$
\text { Disease severity }=\frac{(\mathrm{PN} \times \mathrm{DS})}{\text { total } \mathrm{PN} \times \text { the highest } \mathrm{DS}} \times 100 \%
$$

Note: PN represents plant number; DS represents disease scale.

\subsection{Statistical analysis}

One-way analysis of variance (ANOVA) and Duncan's multiple range test with a significant level of $95 \%(p<0.05)$ were performed to confirm the statistical differences by using IBM SPSS Statistics 19.

\section{Results and discussion}

\subsection{Characterization of GO-Cu NPs}

$\mathrm{Cu}$ NPs were immobilized on the surface of GO by ammonia reductant and stabilizer. The detailed synthesis process is illustrated in Fig. 1. TEM was employed to observe the morphologies of GO and GO-Cu NPs. GO was observed as a thin and semitransparent sheet in Fig. 2A. After the reaction, many dark spots were firmly immobilized on GO sheets (Fig. 2B and C). From the HRTEM image (Fig. 2D), the lattice fringes of these dark spots on GO were measured as $0.209 \mathrm{~nm}$ and assigned to the (111) lattice plane of $\mathrm{Cu} \mathrm{NPs}^{33}$ The size of $\mathrm{Cu}$ NPs, as measured through TEM, was approximately $21.28 \mathrm{~nm}$. Such small particles may enhance antibacterial properties due to more interaction chances with bacteria. ${ }^{9,34}$ The elemental component of as-prepared GO-Cu NPs was determined by EDS and indicated that the GO-Cu NPs composites contained carbon, oxygen, chlorine, and copper elements (Fig. 2E). Among all the elements, copper content accounted for $57.46 \mathrm{wt} \%$ of the GO-Cu NPs. The microstructures of GO and GO-Cu NPs were further revealed by XRD patterns (Fig. 3). A specific XRD pattern with a characteristic peak concerting at $2 \theta=10.43^{\circ}$ was in agreement with the crystal structure of GO. ${ }^{35}$ However, this peak disappeared in the pattern of GO-Cu NPs indicating $\mathrm{Cu}$ NPs changed the surface structure of GO. The diffraction peaks of GO-Cu NPs at diffraction angles of $16.22^{\circ}, 32.26^{\circ}, 39.68^{\circ}$, $50.14^{\circ}$, and $53.42^{\circ}$ were indexed as (101), (113), (024), (033), and (220) crystalline planes, which was similar to the paratacamite crystal $\left(\mathrm{Cu}_{2}(\mathrm{OH})_{3} \mathrm{Cl}\right.$, JCPDS file no. 87-0679). 


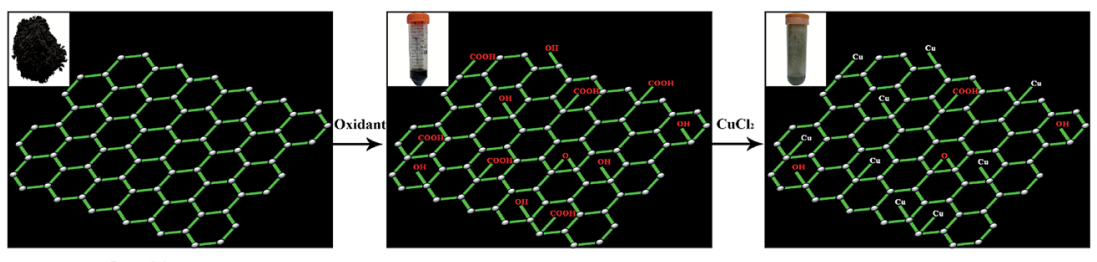

Graphite

GO

GO-Cu NPs

Fig. 1 Schematic representation of the reaction steps leading to the preparation of GO-Cu NPs.


Fig. 2 TEM images of (A) GO and (B and C) GO-Cu NPs; (D) HRTEM image of an individual Cu NPs on GO; (E) EDS pattern of GO-Cu NPs.

FTIR spectroscopy was conducted to detect changes in functional groups. The results of FTIR showed that the spectrum of GO displayed numerous functional groups peaks, including the stretching vibration peaks of $\mathrm{O}-\mathrm{H}\left(3427 \mathrm{~cm}^{-1}\right)$, $\mathrm{C}=\mathrm{C}\left(1655 \mathrm{~cm}^{-1}\right)$ and $\mathrm{C}-\mathrm{O}\left(1286 \mathrm{~cm}^{-1}\right)$, the asymmetric stretching vibration of $\mathrm{C}-\mathrm{H}$ bonds in $-\mathrm{CH}_{3}$ and $-\mathrm{CH}_{2}(2924$ $\left.\mathrm{cm}^{-1}\right)^{36}$ and the in-plane bending vibration of $\mathrm{C}-\mathrm{H}\left(1425 \mathrm{~cm}^{-1}\right)$ (Fig. 4). After the reaction between GO and $\mathrm{Cu}$ NPs, several



Fig. 3 XRD pattern of GO and GO-Cu NPs. changes took place in the function groups. The strong peak at $3427 \mathrm{~cm}^{-1}$ was divided into two adsorptions of O-H stretching vibration at $3446 \mathrm{~cm}^{-1}$ and $3354 \mathrm{~cm}^{-1} .{ }^{37}$ The adsorption band of $\mathrm{C}=\mathrm{C}$ at $1655 \mathrm{~cm}^{-1}$ drifted to $1624 \mathrm{~cm}^{-1}$. $^{38}$ The adsorption bonds at $2924 \mathrm{~cm}^{-1}, 1425 \mathrm{~cm}^{-1}$ and $1286 \mathrm{~cm}^{-1}$ disappeared.

However, some new peaks appeared, including the $\mathrm{O}-\mathrm{H}$ stretching vibration at $1385 \mathrm{~cm}^{-1}, 39$ the $\mathrm{C}-\mathrm{H}$ out-plane bending vibrations at 987,920 , and $847 \mathrm{~cm}^{-1}$ and $\mathrm{Cu}-\mathrm{O}$ stretching vibrations in monoclinic $\mathrm{CuO}$ below $600 \mathrm{~cm}^{-1} .{ }^{40}$ These changes in functional groups suggested that Cu NPs were successfully immobilized on the surface of GO.

\subsection{Antibacterial assay}

Antibacterial activity of GO-Cu NPs on Pst was qualitatively investigated by an agar disk diffusion test. As shown in Fig. 5, GO-Cu NPs were observed by a clear and significant inhibitory zone, while the other treatments had no inhibitory zone. The average diameter value of inhibition zone for GO-Cu NPs was $(14.92 \pm 1.46) \mathrm{mm}$. These results indicated that Kocide 3000 and GO separately have no considerable antibacterial activity at tested concentrations. However, GO-Cu NPs composites have good antibacterial property against Pst.

To study the antibacterial effect of GO-Cu NPs further, the value of MIC was measured using a microdilution broth method. After $48 \mathrm{~h}$ incubation, GO-Cu NPs and Kocide 3000 exhibited good antibacterial activity in a dose-dependent manner (Fig. 6). No colony growth was observed with

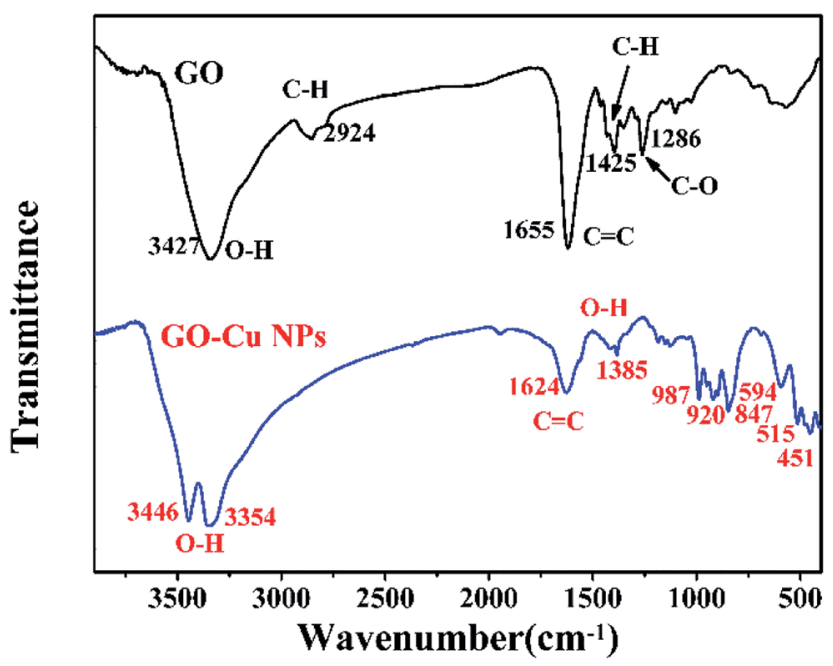

Fig. 4 FTIR spectra of GO and GO-Cu NPs. 


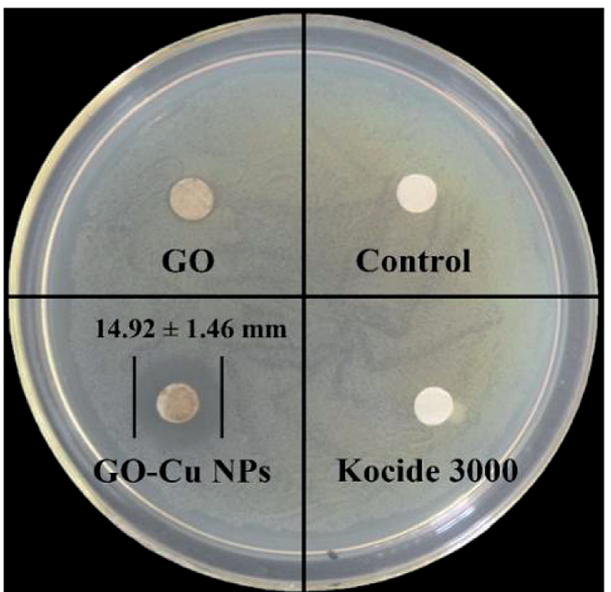

Fig. 5 Inhibitory zone pattern of Kocide 3000, GO and GO-Cu NPs.

treatment of GO-Cu NPs $\left(16 \mu \mathrm{g} \mathrm{mL}{ }^{-1}\right)$ and Kocide 3000 $\left(250 \mu \mathrm{g} \mathrm{mL}^{-1}\right)$. Therefore, the MIC value of GO-Cu NPs was almost 16 times lower than that of Kocide 3000, indicating GO-Cu NPs composites had better antibacterial property. The enhanced antibacterial activity of GO-Cu NPs may be derived from congregated $\mathrm{Cu}$ NPs tending to disperse in the process of application. In our study, $\mathrm{Cu}$ NPs were loaded onto the surface of GO, which could effectively prevent $\mathrm{Cu}$ NPs from aggregation.

Our result was consistent with a previously reported study. ${ }^{41} \mathrm{On}$ the other hand, FTIR results showed GO-Cu NPs composites had some functional groups, such as $\mathrm{C}-\mathrm{O}$, which could greatly improve the dispersive capacity of GO-Cu NPs composites in solution. In addition, it has been reported that GO has strong antibacterial activity against plant pathogenic bacterium. ${ }^{23}$ In our study, GO had no significant antibacterial ability due to its low concentration. Consequently, the enhanced antibacterial effect of GO-Cu NPs might be caused by a synergistic effect between GO and Cu NPs.

\subsection{Observation of the cell morphology change}

According to the previous study, GO sheets tended to nonspecifically wrap the bacteria cells. ${ }^{42}$ Meanwhile, the positive charge of $\mathrm{Cu}$ NPs can bind to the negative charge of bacteria cell
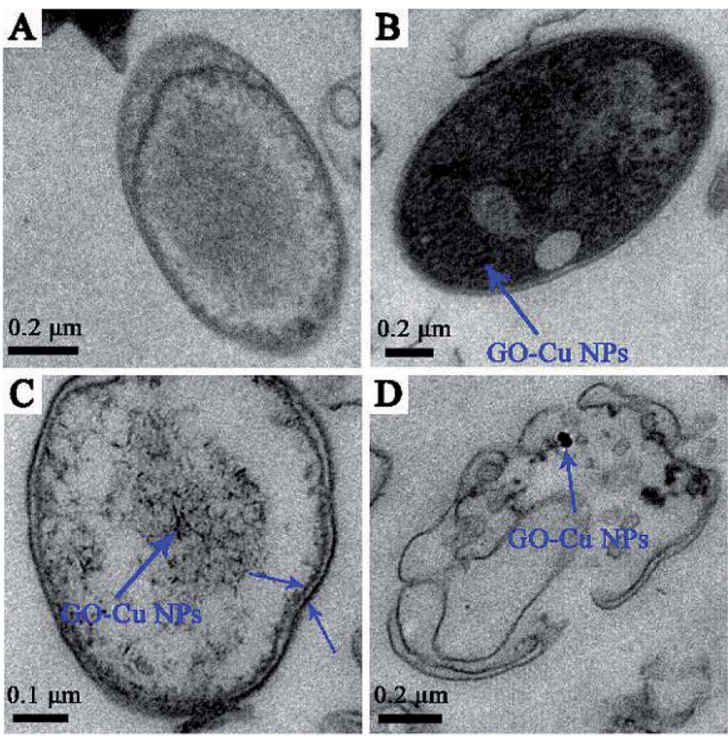

Fig. 7 TEM image of Pst bacterial cells treated with (A) sterile water, and (B-D) GO-Cu NPs.

surfaces and react with phosphorus- and sulfur-containing compounds..$^{\mathbf{3 4 , 4 3 , 4 4}}$ Based on the previous antibacterial results, we further investigated the antibacterial behaviour of $\mathrm{GO}-\mathrm{Cu}$ NPs throughout using TEM. Results showed that the untreated cells displayed intact structures without morphological changes (Fig. 7A). However, after incubation with GO-Cu NPs, the nanoparticles were adsorbed onto the cell membrane/wall (Fig. 7B) and then penetrated the cell Fig. 7C which was likely due to a change of cell permeability. ${ }^{45} \mathrm{Cu}$ NPs inside the cells could react with the intercellular structure, and then damaged it. Consequently, disorganization of the bacterial membrane and damage of the cellular structure leads to bacteria cell death (Fig. 7D).

\subsection{Intracellular reactive oxygen species (ROS)}

ROS generation is regarded as one of the critical antibacterial mechanisms of Cu NPs. ${ }^{46,47}$ A high level of ROS inside cells can perturb the redox potential equilibrium, produce a pro-oxidant

\section{$250 \mu \mathrm{g} / \mathrm{mL} \quad 125 \mu \mathrm{g} / \mathrm{mL} \quad 62.5 \mu \mathrm{g} / \mathrm{mL} \quad 32 \mu \mathrm{g} / \mathrm{mL} \quad 16 \mu \mathrm{g} / \mathrm{mL} \quad 8 \mu \mathrm{g} / \mathrm{mL} \quad$ Control}

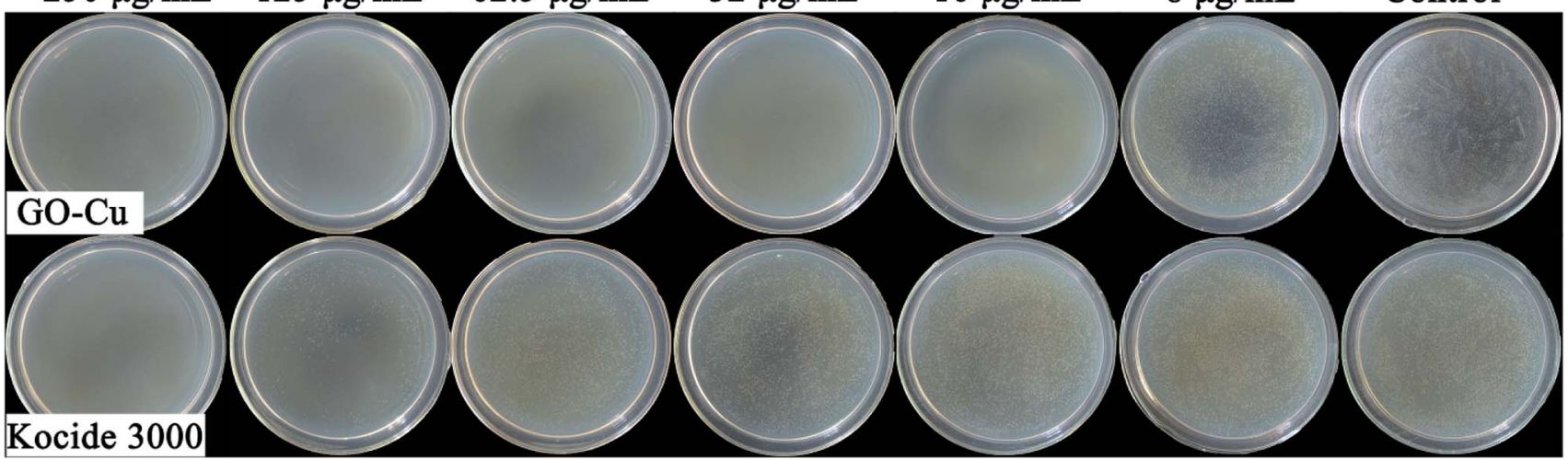

Fig. 6 Minimum inhibitory concentration of Kocide 3000 and GO-Cu NPs. 
environment, and further result in a range of adverse biological responses. ${ }^{48}$ In order to investigate the level of ROS inside the GO-Cu NPs-exposed Pst cells, DCFH-DA was introduced as a visual indicator for the oxidative status of a cell; fluorescent intensity of DCF is positively correlated with the amount of ROS. Compared with the control, GO-treated cells had no noticeable increase of ROS (Fig. 8), which was in agreement with a previous report. ${ }^{42}$ However, the level of ROS in the GO-Cu NPs treated cells was significantly increased (almost 1.9 times more than the control). Such a significant increase of intercellular ROS can lead to a strong oxidative environment inside the cells, which mediates oxidative damage to membrane lipids, proteins, DNA, and other compounds. ${ }^{48}$

\subsection{DNA damage caused by GO-Cu NPs}

Both Cu NPs and intercellular ROS are known to target cellular DNA, leading to DNA strand breaks and blocking DNA replication. ${ }^{\mathbf{4 6 9}}$ Released $\mathrm{Cu}$ ions from $\mathrm{Cu}$ NPs inside bacteria cells can bind strongly to DNA at binding sites and react with cellular ROS, producing hydroxyl radicals which immediately attacked the DNA bases. $^{49,50}$ In order to investigate the fate of DNA from Pst cells with exposure to GO-Cu NPs, the DNA was extracted and analysed by electrophoresis. The intensity of a DNA band in agarose gel has a positive relation with the DNA concentration. From the result (Fig. 9), a strong DNA band was observed from the control treatment (lane 1). However, the DNA concentration decreased with an increase of GO-Cu NPs concentration (lanes 2 to 6) as compared to the control treatment (lane 1). No DNA band was observed in the samples treated with GO-Cu NPs at $32 \mu \mathrm{g} \mathrm{mL}{ }^{-1}$ and above due to their complete inhibition to Pst cells growth (lanes 4 to 6). In the case of the cells incubated with Kocide 3000 at $250 \mu \mathrm{g} \mathrm{mL}$ (lane 7), the DNA concentration was similar to that of GO-Cu NPs at $16 \mu \mathrm{g} \mathrm{mL} \mathrm{m}^{-1}$ (lane 3), due to their similar effects in the MIC test.

According to the above results, the antibacterial mechanism of GO-Cu NPs was proposed as follows (Fig. 10): when GO-Cu

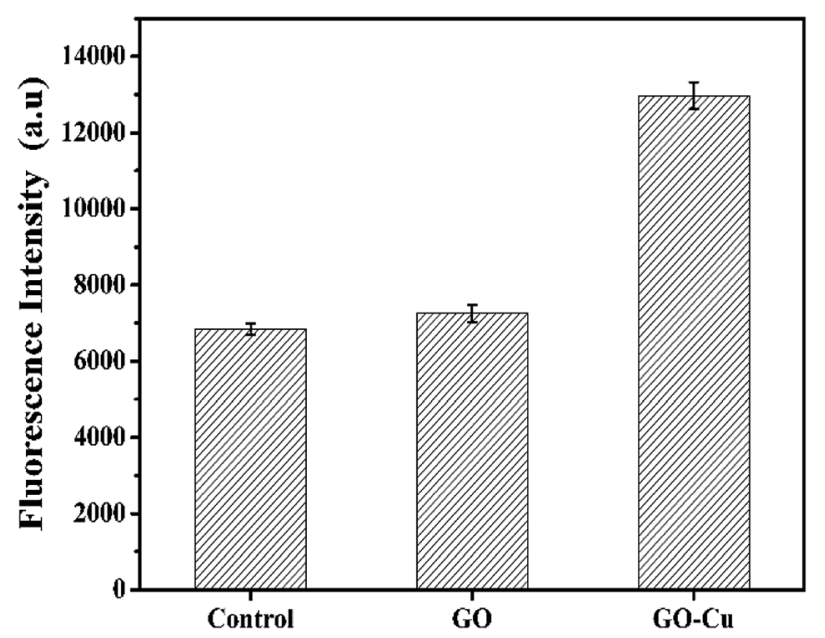

Fig. 8 Formation of ROS in Pst cells after $2 \mathrm{~h}$ incubation with GO and GO-Cu NPs. Means followed by the same letter are not significantly different at $p \leq 0.05$ based on Duncan. The error bar represents standard error of the mean.

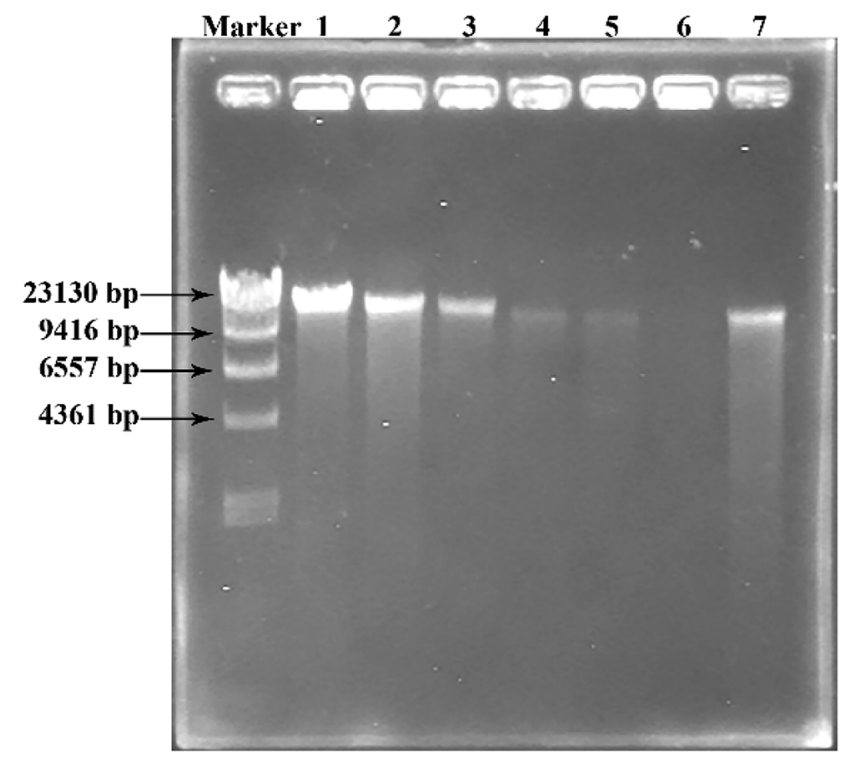

Fig. 9 Electrophoresis analysis of DNA from Pst cells treated with different concentrations of the GO-Cu NPs for $2 \mathrm{~h}$ (lanes 1-7 represent the treatments of $0,8,16,32,62.5,125 \mu \mathrm{g} \mathrm{mL}^{-1}$ of GO-Cu NPs and $250 \mu \mathrm{g} \mathrm{mL}^{-1}$ of Kocide 3000 , respectively).

NPs were exposed to Pst cells, the $\mathrm{Cu}$ NPs were released from GO-Cu NPs and adhered to the bacteria cell surfaces. Then the $\mathrm{Cu}$ NPs reacted with the membrane protein, leading to increased cell permeability which damaged the integrity of cell membrane/wall. Therefore, $\mathrm{Cu}$ NPs on a cell surface can penetrate inside the cells, which causes serious damage by reacting with DNA and other intracellular compounds. These reactions could produce a high level of ROS which mediated strong oxidative stress in the cell. The membrane lipids, proteins, DNA, and other compounds were subsequently degraded under

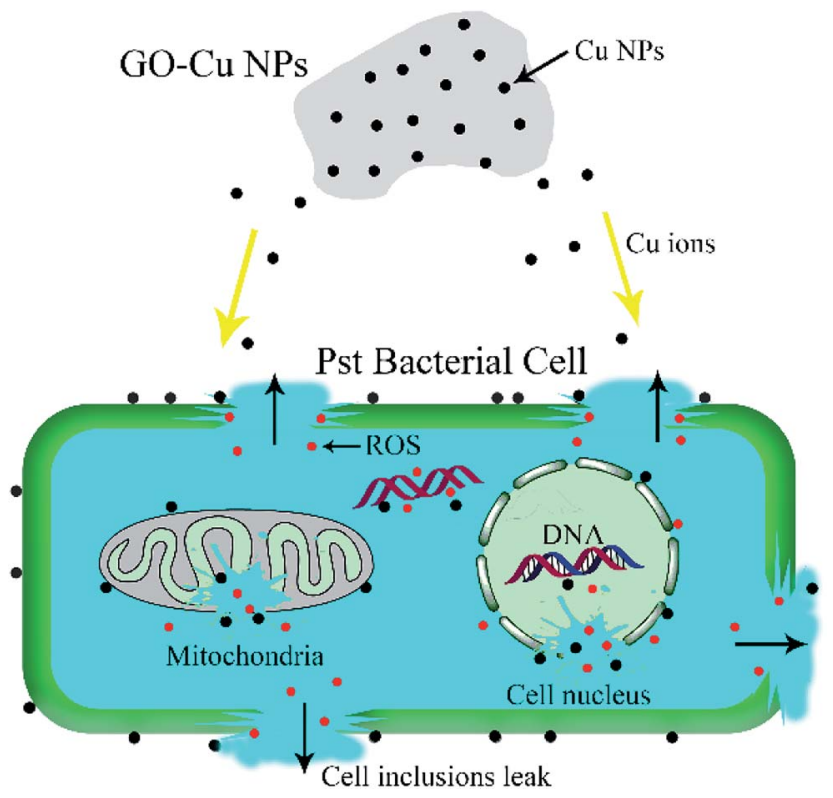

Fig. 10 The antibacterial model of GO-Cu NPs against Pst cells. 

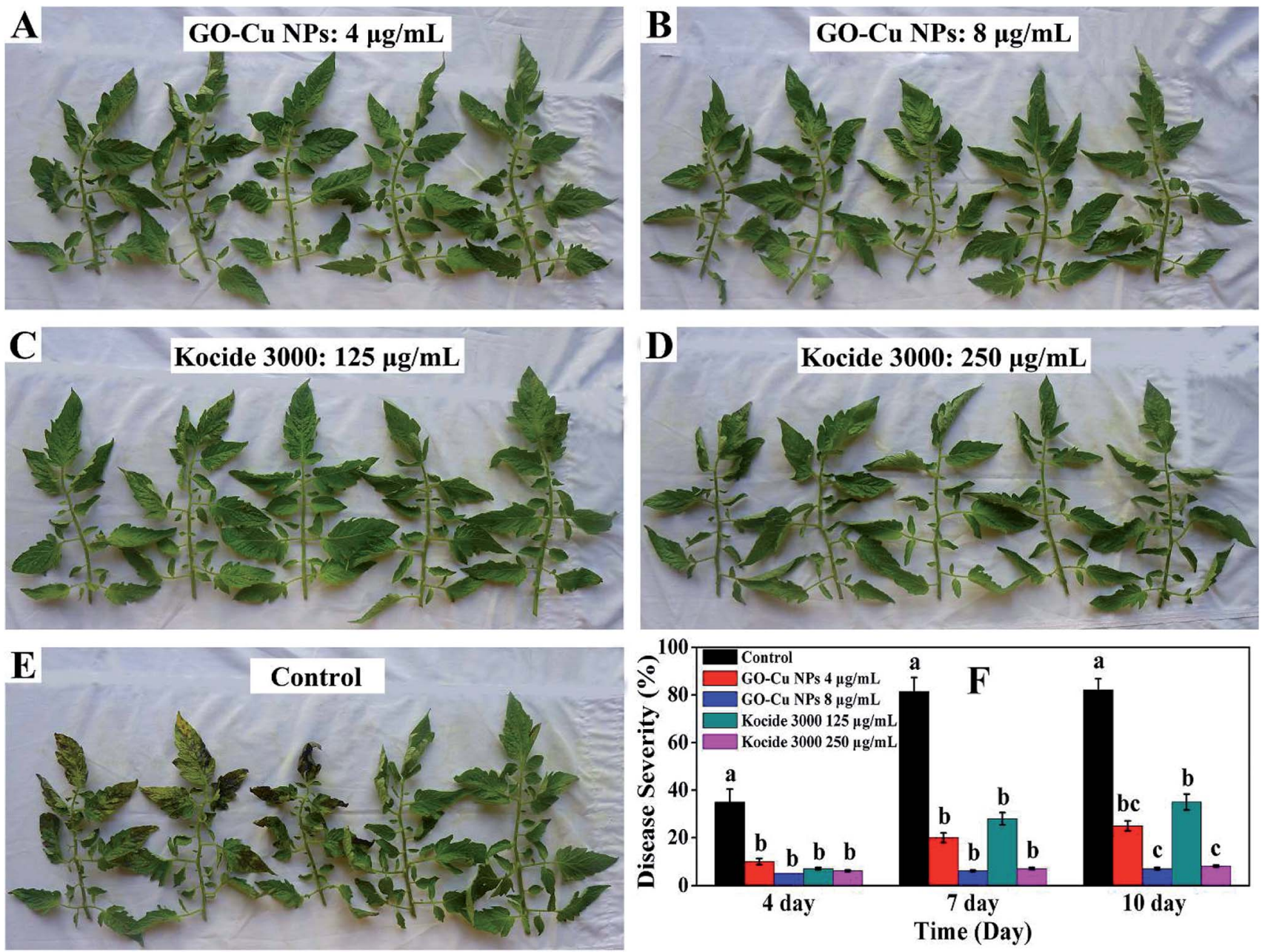

Fig. 11 Treatments of tomato transplants with GO-Cu NPs: (A) $4 \mu \mathrm{g} \mathrm{mL}^{-1}$, (B) $8 \mu \mathrm{g} \mathrm{mL}^{-1}$, Kocide 3000: (C) $125 \mu \mathrm{g} \mathrm{mL}{ }^{-1}$, (D) $250 \mu \mathrm{g} \mathrm{mL}$ sterile water. (F) The severity of bacterial speck 4, 7 and 10 days after treatment. Means are followed by the same letter.

the oxidative environment. Finally, bacteria cells were thoroughly killed.

\subsection{Effectiveness of GO-Cu NPs against bacterial speck on tomato}

To further investigate practical efficiency, GO-Cu NPs were applied to tomato transplants to control bacterial speck. The severity of the disease was recorded after 4, 7, and 10 days (Fig. 11). Results indicated that tomatoes treated with GO-Cu NPs had no obvious bacterial speck after the fourth day (Fig. 11A and B). Even after 10 days, the disease severity on tomato leaves treated with $\mathrm{GO}-\mathrm{Cu}$ NPs was still below $25 \%$ (Fig. 11F). When treated with Kocide 3000 at 125 and $250 \mu \mathrm{g} \mathrm{mL}^{-1}$, the disease severity was below $35 \%$ at the 10 th day (Fig. 11C, D and F). However, with the control treatment, a large number of bacterial specks were observed (Fig. 11E). Bacterial speck severity increased from $35 \%$ at the fourth day to over $80 \%$ at the tenth day (Fig. 11F). In addition, treated tomatoes with GO-Cu NPs had no phytotoxicity. Although there was no significant difference between the control effects of the two agents, the concentration of Kocide 3000 was more than
32 times higher than GO-Cu NPs. It was concluded that the GO-Cu NPs have better antibacterial activity than Kocide 3000 .

\section{Conclusions}

Copper oxide nanoparticles were successfully loaded on the surface of GO by a facile chemical reduction method in aqueous solutions with the assistance of ammonia water. It was found that GO-Cu NPs have excellent antibacterial activity at extremely low concentrations. Investigation of the antibacterial mechanism showed that a GO-Cu NPs composite could lead to damaging the cell structure, increasing the level of reactive oxygen species, and decreasing the content of DNA in bacterial cells. The in vivo test on tomato plants indicated that GO-Cu NPs could reduce the severity of bacterial speck without phytotoxicity. Therefore, it is important and valuable to explore potential applications of this composite as a biocide for managing crop diseases.

\section{Acknowledgements}

This work was supported by National Natural Science Foundation of China (Grant No. 41401564), Guangdong Science and 
Technology Plan Program (2014A030313706), Science and Technology Program of Guangzhou, China (1563000751) and Opening Fund of Key Laboratory of Integrated Pest Management on Crops in Northwestern Oasis of Ministry of Agriculture (KFJJ20170105).

\section{Notes and references}

1 M. K. Bryan, Phytopathology, 1933, 23, 897-904.

2 H. Yunis, Y. Bashan, Y. Okon and Y. Henis, Plant Dis., 1980, 64, 937-939.

3 R. Lanna Filho, R. M. de Souza, A. Ferreira, M. C. Quecine, E. Alves and J. L. de Azevedo, Australas. Plant Pathol., 2013, 42, 643-651.

4 K. C. Conlin, Plant Dis., 1983, 67, 639-644.

5 W. G. Bonn and S. Lesage, J. Environ. Sci. Health, Part B, 1984, 19, 29-38.

6 C. K. Bower and M. A. Daeschel, Int. J. Food Microbiol., 1999, 50, 33-44.

7 F. J. Louws, M. Wilson, H. L. Campbell, D. A. Cuppels, J. B. Jones, P. B. Shoemaker, F. Sahin and S. A. Miller, Plant Dis., 2001, 85, 481-488.

8 W. Zhang, F. Jiang and J. Ou, Proc. Int. Acad. Ecol. Environ. Sci., 2011, 1, 125-144.

9 J. R. Morones, J. L. Elechiguerra, A. Camacho, K. Holt, J. B. Kouri, J. T. Ramírez and M. J. Yacaman, Nanotechnology, 2005, 16, 2346-2353.

10 M. A. Salam, A. Y. Obaid, R. El-Shishtawy and S. A. Mohamed, RSC Adv., 2017, 7, 16878-16884.

11 K. Sunada, Y. Kikuchi, K. Hashimoto and A. Fujishima, Environ. Sci. Technol., 1998, 32, 726-728.

12 C. O. Dimkpa, J. E. McLean, D. W. Britt and A. J. Anderson, BioMetals, 2013, 26, 913-924.

13 I. Ocsoy, M. L. Paret, M. A. Ocsoy, S. Kunwar, T. Chen, M. You and W. Tan, ACS Nano, 2013, 7, 8972-8980.

14 C. Marambio-Jones and E. M. V. Hoek, J. Nanopart. Res., 2010, 12, 1531-1551.

15 J. Cui and Y. Liu, RSC Adv., 2015, 5, 85748-85755.

16 J. Cui, Y. Liang, D. Yang and Y. Liu, Sci. Rep., 2016, 6, 21423.

17 J. Cui, Y. Yang, Y. Hu and F. Li, J. Colloid Interface Sci., 2015, 455, 117-124.

18 M. Young and S. Santra, J. Agric. Food Chem., 2014, 62, 60436052.

19 U. Bogdanović, V. Lazić, V. Vodnik, M. Budimir, Z. Marković and S. Dimitrijević, Mater. Lett., 2014, 128, 75-78.

20 S. Pradhan, P. Patra, S. Mitra, K. K. Dey, S. Basu, S. Chandra, P. Palit and A. Goswami, J. Agric. Food Chem., 2015, 63, 26062617.

21 V. Saharan, R. V. Kumaraswamy, R. C. Choudhary, S. Kumari, A. Pal, R. Raliya and P. Biswas, J. Agric. Food Chem., 2016, 64, 6148-6155.

22 H. L. Karlsson, P. Cronholm, J. Gustafsson and L. Moller, Chem. Res. Toxicol., 2008, 21, 1726-1732.

23 J. Chen, H. Peng, X. Wang, F. Shao, Z. Yuan and H. Han, Nanoscale, 2014, 6, 1879-1889.

24 V. Chabot, D. Higgins, A. Yu, X. Xiao, Z. Chen and J. Zhang, Energy Environ. Sci., 2014, 7, 1564-1596.
25 W. Liu, C. Sun, C. Liao, L. Cui, H. Li, G. Qu, W. Yu, N. Song, Y. Cui, Z. Wang, W. Xie, H. Chen and Q. Zhou, J. Agric. Food Chem., 2016, 64, 5909-5918.

26 R. Karthik, M. Govindasamy, S.-M. Chen, T.-W. Chen, J. Vinoth kumar, A. Elangovan, V. Muthuraj and M.-C. Yu, RSC Adv., 2017, 7, 25702-25709.

27 D. R. Dreyer, S. Park, C. W. Bielawski and R. S. Ruoff, Chem. Soc. Rev., 2010, 39, 228-240.

28 M. Zhang, B. Gao, J. Chen and Y. Li, J. Nanopart. Res., 2015, 17, 1-8.

29 W. S. Hummers and R. E. Offeman, J. Am. Chem. Soc., 1958, 80, 1339.

30 K. Fiebelkorn, S. Crawford, M. McElmeel and J. Jorgensen, J. Clin. Microbiol., 2003, 41, 4740-4744.

31 I. Wiegand, K. Hilpert and R. E. W. Hancock, Nat. Protoc., 2008, 3, 163-175.

32 C. P. LeBel, H. Ischiropoulos and S. C. Bondy, Chem. Res. Toxicol., 1992, 5, 227-231.

33 V. A. Phillips and J. A. Hugo, Micron, 1969, 1971(3), 212-223.

34 M. Raffi, S. Mehrwan, T. M. Bhatti, J. I. Akhter, A. Hameed, W. Yawar and M. M. ul Hasan, Ann. Microbiol., 2010, 60, 75-80.

35 J. Ma, J. Zhang, Z. Xiong, Y. Yong and X. Zhao, J. Mater. Chem., 2011, 21, 3350-3352.

36 J. Liu, H. Bai, Y. Wang, Z. Liu, X. Zhang and D. D. Sun, Adv. Funct. Mater., 2010, 20, 4175-4181.

37 J. Chen, X. Wang and H. Han, J. Nanopart. Res., 2013, 15, 1658.

38 Q. Chen, L. Zhang and G. Chen, Anal. Chem., 2011, 84, 171178.

39 Y. Huang, Y. Qin, Y. Zhou, H. Niu, Z.-Z. Yu and J.-Y. Dong, Chem. Mater., 2010, 22, 4096-4102.

40 Y. Xu, D. Chen and X. Jiao,J. Phys. Chem. B, 2005, 109, 1356113566.

41 D. Zhang, X. Liu and X. Wang, J. Inorg. Biochem., 2011, 105, 1181-1186.

42 S. Liu, T. H. Zeng, M. Hofmann, E. Burcombe, J. Wei, R. Jiang, J. Kong and Y. Chen, ACS Nano, 2011, 5, 69716980.

43 P. K. Stoimenov, R. L. Klinger, G. L. Marchin and K. J. Klabunde, Langmuir, 2002, 18, 6679-6686.

44 T. J. Beveridge and R. G. Murray, J. Bacteriol., 1980, 141, 876887.

45 Y. Ohsumi, K. Kitamoto and Y. Anraku, J. Bacteriol., 1988, 170, 2676-2682.

46 M. Shi, H. S. Kwon, Z. Peng, A. Elder and H. Yang, ACS Nano, 2012, 6, 2157-2164.

47 M. Valko, H. Morris and M. T. D. Cronin, Curr. Med. Chem., 2005, 12, 1161-1208.

48 N. Ercal, H. Gurer-Orhan and N. Aykin-Burns, Curr. Trends Med. Chem., 2001, 1, 529-539.

49 J.-L. Sagripanti, P. L. Goering and A. Lamanna, Toxicol. Appl. Pharmacol., 1991, 110, 477-485.

50 O. I. Aruoma, B. Halliwell, E. Gajewski and M. Dizdaroglu, Biochem. J., 1991, 273, 601-604. 